\title{
Distribusi Kasus Leptospirosis di Kabupaten Demak Jawa Tengah
}

\author{
Kuswati $^{1}$, Suhartono ${ }^{2}$, Nurjazuli ${ }^{2}$ \\ 1) Dinas Kesehatan Kabupaten Demak. \\ ${ }^{2}$ ) Program Magister Kesehatan Lingkungan Fakultas Kesehatan Masyarakat, Universitas Diponegoro
}

Info Artikel : Diterima September 2016 ; Disetujui Oktober 2016 ; Publikasi Oktober 2016

\begin{abstract}
Title: Distribution of Leptospiosis Incidence in Demak District, Central Java

Background: Leptospirosis is zoonotic disease caused by Leptospira bacteria and transmitted to human through contact with animal urine into contaminated environment. Demak District is one of the endemic area in Central - Java. The number of cases is fluctuative over the year 2011-2016 with the peak of 20 cases in 2011, and It decreased at low number in 2016. Many factors may contributed such as water puddle, rat, and behaviour. Nowdays, the information about the distribution and spreading of cases was lacking. The purpose of this study was to describe the leptospiroses incidence based on the epidemiological variable and spatially in Demak District.
\end{abstract}

Method: It was an observational research using cross sectional design. The subjects were 89 cases over the year 2011-2016. The variables studied consisted of epidemiological variabels (man, place, and time), physical and biological environment factors, and behaviour aspects. Interviews and observation were conducted as the data collection techniques. The collected data would be analysed descriptively and spatially.

Result: The results of this research showed that the lepstospirosis incidence was-suffered more by male (66\%) compared to female. Most of them (67,4\%) were farmers. The peak of leptospirosis incidence occured in 2011. The existence of water puddle around the house, and drainage functioning as the media where the rat died. There were rats in the house where the cases occured (98,7\%). Most of the subjects (66,7\%) stated that they did their activities everyday in bare foot. Spatial analysis showed that Mranggen and Karangawen sub district had high numbers of leptospirosis cases.

Conclusion: Most of the leptispirosis cases were suffered more by male compared to female and the subjects worked as farmers. Mranggen and Karangnawen were two districts with high incidence of leptospirosis relatively. These areas held a history as flooding areas in previous time.

Keywords: Environmental factors; behavioral factors; leptospirosis; Demak.

\section{PENDAHULUAN}

Leptospirosis adalah penyakit zoonosis, yang disebabkan oleh infeksi bakteri yang berbentuk spiral dari genus Leptospira. Leptospirosis tersebar luas di seluruh dunia, terutama pada daerah tropis dan subtropis. ${ }^{1}$ Di Indonesia kasus klinis leptospirosis dilaporkan pertama kali oleh Vander Scheer di Jakarta pada tahun 1892, sedangkan isolasinya dilakukan oleh Vervoot pada tahun $1922 .^{2}$

Di Indonesia, leptospirosis tersebar antara lain di Provinsi Jawa Barat, Provinsi Jawa Tengah, Daerah Istimewa Yogyakarta, Provinsi Lampung, Provinsi Sumatera Selatan, Bengkulu, Riau, Sumatera Barat, Sumatera Utara, Bali, Nusa Tenggara Barat, Sulawesi
Selatan, Sulawesi Utara, Kalimantan Timur dan Kalimantan Barat. Angka kematian akibat leptospirosis termasuk tinggi, mencapai 2,5-16,45 persen. Pada usia lebih dari 50 tahun kematian mencapai 56 persen. Penderita leptospirosis yang disertai selaput mata kuning (kerusakan jaringan hati), mempunyai risiko kematian akan lebih tinggi ${ }^{3}$, angka kematian di rumah sakit karena leptospirosis $3-54 \%$ dan tergantung dari sistem organ yang terinfeksi. ${ }^{4}$ Data dari International Leptospirosis Society (ILS), Indonesia merupakan negara peringkat 3 (tiga) insiden leptospirosis di dunia setelah India dan Cina untuk mortalitas. ${ }^{5}$

Data dari Dinas Kesehatan Kabupaten Demak menunjukkan jumlah kasus leptospirosis tahun 2010- 
2015 mengalami fluktuasi. Tahun 2010 ditemukan 33 kasus dan meninggal 3 orang (CFR: 9,09\%), tahun 2011 ditemukan 20 kasus dan 1 orang meninggal (CFR: 5,00\%), tahun 2012 ditemukan 13 kasus dan 2 orang meninggal (CFR: 15,38\%), tahun 2014 ditemukan 21 kasus dan 4 orang meninggal (CFR: 19,05\%), tahun 2015 ditemukan 11 dan tidak ada yang meninggal. ${ }^{6}$

Beberapa penelitian tentang faktor risiko pernah dilakukan di Kabupaten Demak. Penelitian yang dilakukan pada tahun 2008 menunjukkan bahwa faktor risiko kejadian leptospirosis di Kabupaten Demak meliputi pekerjaan yang melibatkan kontak tubuh dengan air $(\mathrm{OR}=17,36)$, keberadaan tikus di dalam dan sekitar rumah $(\mathrm{OR}=10,34)$, kebiasaan mandi dan cuci di sungai $\mathrm{OR}=12,24 .{ }^{7}$ Penelitian lain yang dilakukan di Semarang menunjukkan bahwa faktor-faktor yang berkaitan dengan kejadian leptospirosis higiene perorangan (yang meliputi kebiasaan mandi $\mathrm{OR}=2,48$, riwayat adanya luka $\mathrm{OR}=5,71$, perawatan luka $\mathrm{OR}=2,68$ ), dan keadaan sanitasi lingkungan (adanya sistem pembuangan air limbah $\mathrm{OR}=2,30$ dan aliran air selokan yang tidak baik $\mathrm{OR}=3.00) .{ }^{8}$ Penelitian yang dilakukan di dua kabupaten (Demak dan Pati) menunjukkan bahwa faktor risiko kejadian leptospirosis adalah adanya genagan air $(\mathrm{OR}=3,5)$, kebiasanan mandi dan cuci di sungai $(\mathrm{OR}=7,5) .{ }^{9}$

Berdasarkan uraian di atas memperlihatkan sudah ada beberapa penelitian faktor risiko kejadian leptospirosis di Kabupaten Demak dan daerah lain. Namun gambaran bagaimana distribusi kasus leprospirosis di Kabupaten Demak masih sangat kurang. Oleh karena itu penelitian ini dilakukan dengan tujuan untuk mengkaji bagaimana distribusi kejadian leptospirosis dilihat dari aspek variabel epidemiologi dan karakteristik wilayah di Kabupaten Demak.

\section{MATERI DAN METODE}

Penelitian ini adalah penelitian observasional deskriptif dengan rancangan cross sectional. Populasi dan sampel penelitian adalah seluruh kasus leptospitrosis yang pernah terjadi pada tahun 20152016. Data diambil dari register yang ada di Dinas Kesehatan Kabupaten Demak. Variabel yang diteliti adalah variabel epidemiologi yang meliputi distribusi menurut orang, tempat, dan waktu, variabel lingkungan fisik (genangan air, ROB, kondisi selokan/drainase, keberadaan sungai), lingkungan biologis (keberadaan tikus dan hewan peliharaan lain), serta variabel perilaku (kebiasaan memakai alas kaki dan mandi). Data penelitian danalisis secara deskriptif dan sebaran kasus dianalisis secara spasial berdasarkan karakteristik koordinat geografis tempat tinggal kasus filariasis di Kabupaten Demak.

\section{HASIL DAN PEMBAHASAN \\ Distribusi kasus leptospirosis menurut variabel epidemiologi (orang, tempat, dan waktu)}

Berdasarkan gambar 1 nampak bahwa sebagian besar $(66 \%)$ kasus leptospirosis yang pernah terjadi berjenis kelamin laki-laki. Hasil penelitian ini hampir sama dengan penelitian di Kulonprogo tahun 2011 yang menyatakan bahwa kasus leptospirosis banyak diderita oleh kaum laki-laki sebanyak 63,3\%. Proporsi kasus yang tinggi pada laki-laki kemungkinan berhubungan dengan pekerjaan, sebagian besar penderita leptopsirosis bekerja sebagai petani yang lebih banyak dikerjakan oleh laki-laki, sementara perempuan hanya membantu sewaktu-waktu. Penderita leptospirosis laki-laki berisiko menderita leptospirosis 9,6 kali lebih besar daripada perempuan. ${ }^{10}$
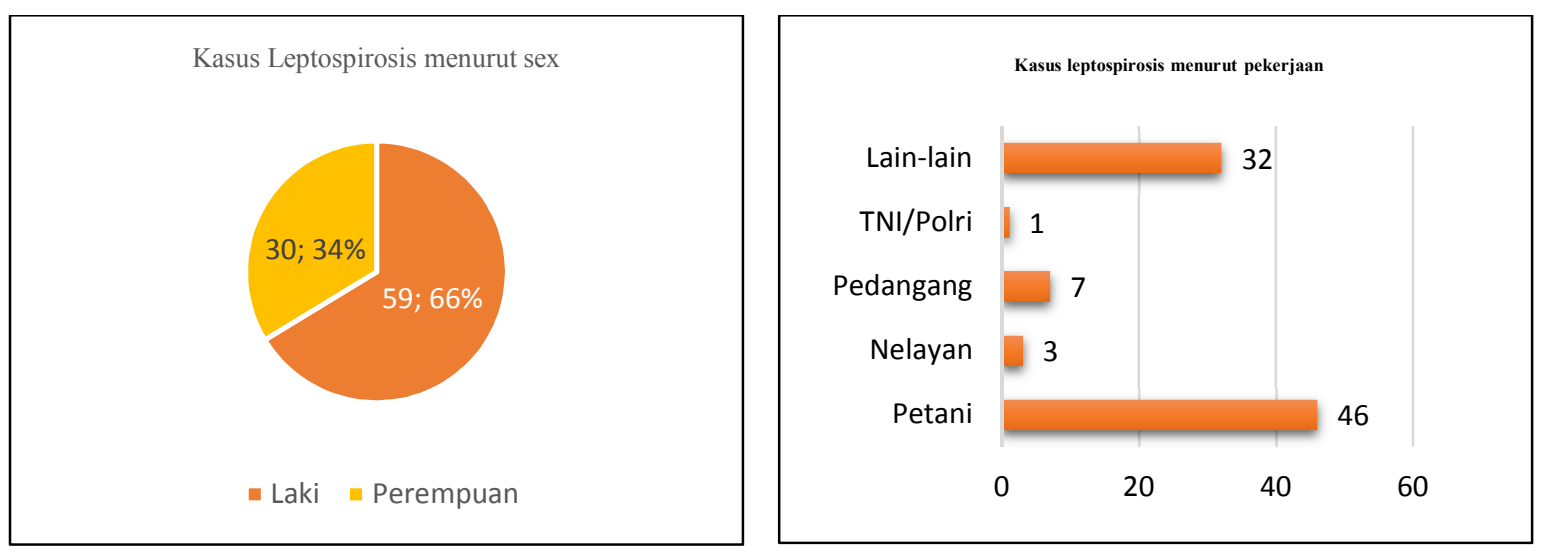

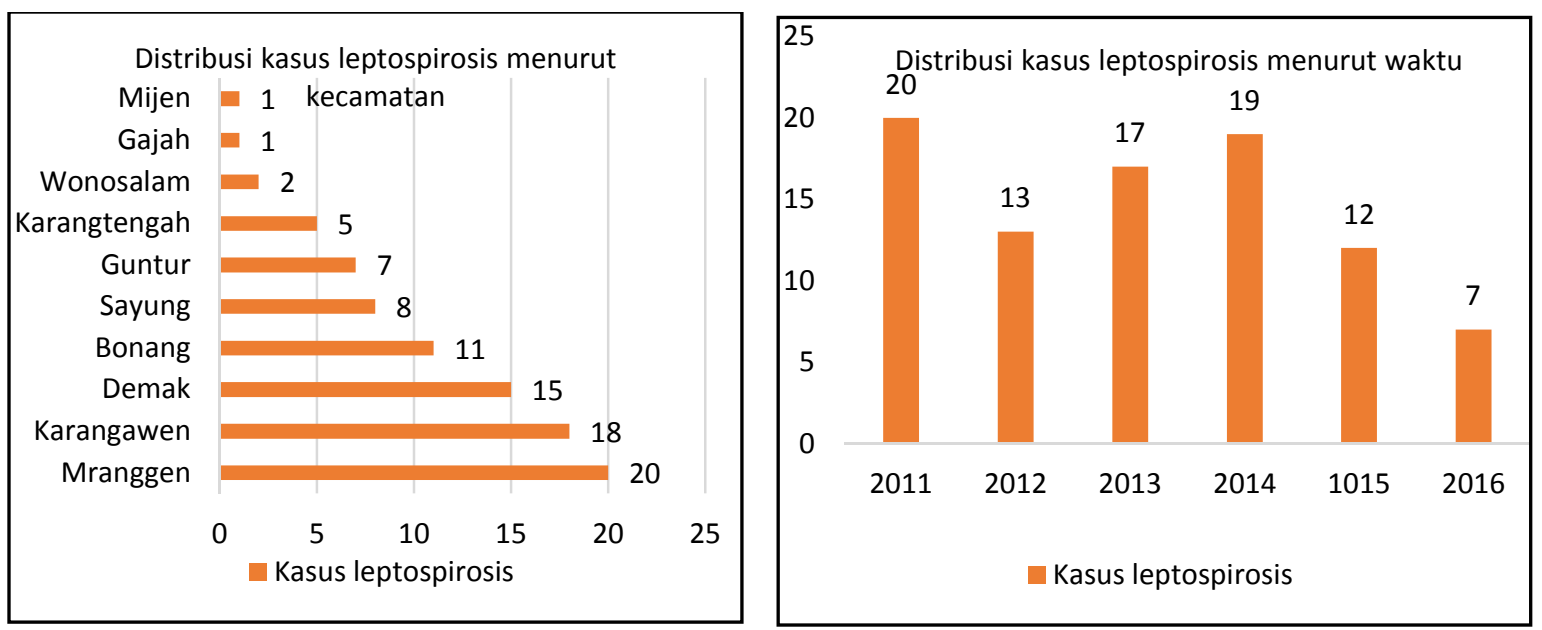

Gambar 1. Distribusi kasus leptospirosis menurut variabel orang di Kabupaten Demak, 2011-2016

Sebagian besar kasus leptospirosis $(67,4 \%)$ mempunyai pekerjaan sebagai petani. Selain itu, kasus leptospirosis juga banyak didertita oleh masyarakat yang mempunyai pekerjaan lain-lain $(35,9 \%)$ seperti tukang batu dan buruh. Para buruh tentunya banyak bekerja di luar rumah yang sangat berisiko terkena leptospirosis. Seperti yang dinyatakan WHO bahwa penyakit ini terutama beresiko terhadap orang yang bekerja di luar ruangan bersama hewan, misal peternak, petani, dokter hewan dan personil militer. ${ }^{11}$

Menurut wilayah kecamatan, kasus leptospirosis tersebar di 10 wilayah kecamatan selama tahun 20112016. Kecamatan Mranggen, Karangawen dan Demak menduduki 3 peringkat teratas, masing-masing 20, 18, dan 15 kasus. Selama kurun waktu 2011-2016, kejadian leptospirosis berfluktuasi. Puncak kasus terjadi pada tahun 2011 (20 kasus), kemudian menurun pada tahun berikutnya dan meningkat lagi mencapai puncak pada tahun 2014 (19 kasus). Tahun berikutnya menurun lagi dan pada tahun 2016 mencapai titik terendah ( 7 kasus). Hal ini agak sedikit berbeda dengan penelitian Farida pada periode sebelumnya. Hasil penelitian tersebut menyatakan bahwa kasus terbanyak terjadi di Kecamatan Demak, disusul Kecamatan Bonang dan Karangawen. ${ }^{12}$ Namun demikian Kecamatan Demak dan Karangawen merupakan daerah dengan kasus yang selalu relatif tinggi dibanding kecamatan lainnya.

\section{Distribusi spasial kasus leptospirosis}

Selama kurun waktu 2011-2016, telah terjadi 89 kasus leptospirosis di Kabupaten Demak. Namun informasi bagaimana sebaran kasus tersebeut secara geografis belum ada. Oleh karena itu, penelitian ini akan melakukan analisis sebaran kasus secara geografis menggunakan ArcGis. Pengukuran koordinat rumah kasus menggunakan pesawat GPS (Geographic Positioning System). Hasil pengukuran koordinat dilakukan plotting ke dalam peta wilayah Kabupaten Demak. Hasil analisis secara spasial seperti pada gambar 2 .
Berdasarkan gambar 2, selama kurun waktu 2011-2016 kasus leptospirosis banyak terjadi dan lebih terkonsentrasi di wilayah Kabupaten Demak bagian selatan yaitu di Kecamatan Mranggen dan Karangawen. Kedua kecamatan ini tidak berbatasan dengan daerah pantai. Namun dari riwayatnya, wilayah tersebut dulunya merupakan daerah rawan banjir, dan berbatasan dengan wilayah Kota Semarang dan Kabupaten Semarang. Kecamatan lain yang cukup banyak terjadi kasus leptospirosis adalah Kecamatan Demak, Bonang dan Sayung. Hal ini juga sesuai dengan penelitian sebelumnya yang mendapatkan bahwa Kecamatan Demak dan Karangawen merupakan wilayah yang mempunyai kasus dengan jumlah lebih banyak dibanding wilayah kecamatan lainnya. ${ }^{12}$ Penelitian lain yang dilakukan Bina juga menemukan bahwa Kecamatan Demak dan Bonang mempunyai jumlah kasus tertinggi. ${ }^{13}$ Namun kedua penelitian sebelumnya ini tidak menemukan kasus leptospirosis di Kecamatan Mranggen. Sedangkan penelitian ini mendapatkan hasil bahwa Mranggen merupakan wilayah kecamatan dengan jumlah kasus tertinggi.

\section{Kondisi Lingkungan fisik}

Kondisi lingkungan dimana penderita bertempat tinggal merupakan faktor yang berkontribusi terhadap kejadian leptospirosis di Kabupaten Deman. Tabel 1 merupakan hasil observasi kondisi lingkungan.

Hasil pengamatan terhadap lingkungan fisik menunjukkan bahwa sebanyak 41,8\% tempat tinggal penderita leptospirosis adalah daerah banjir. Pada saat banjir, sebanyak $15,2 \%$ penderita menyatakan air banjir sering masuk ke dalam rumah. Hanya sebagian kecil penderita $(6,3 \%)$ yang menyatakan bahwa tempat tinggal mereka adalah daerah ROB. Keberadaan genangan air merupakan media penularan penyakit leptospirosis. Hasil pengamatan di sekitar rumah pendertita ditemukan sebanyak $73,1 \%$ penderita meyatakan ada genangan air di sekitar rumah mereka. 


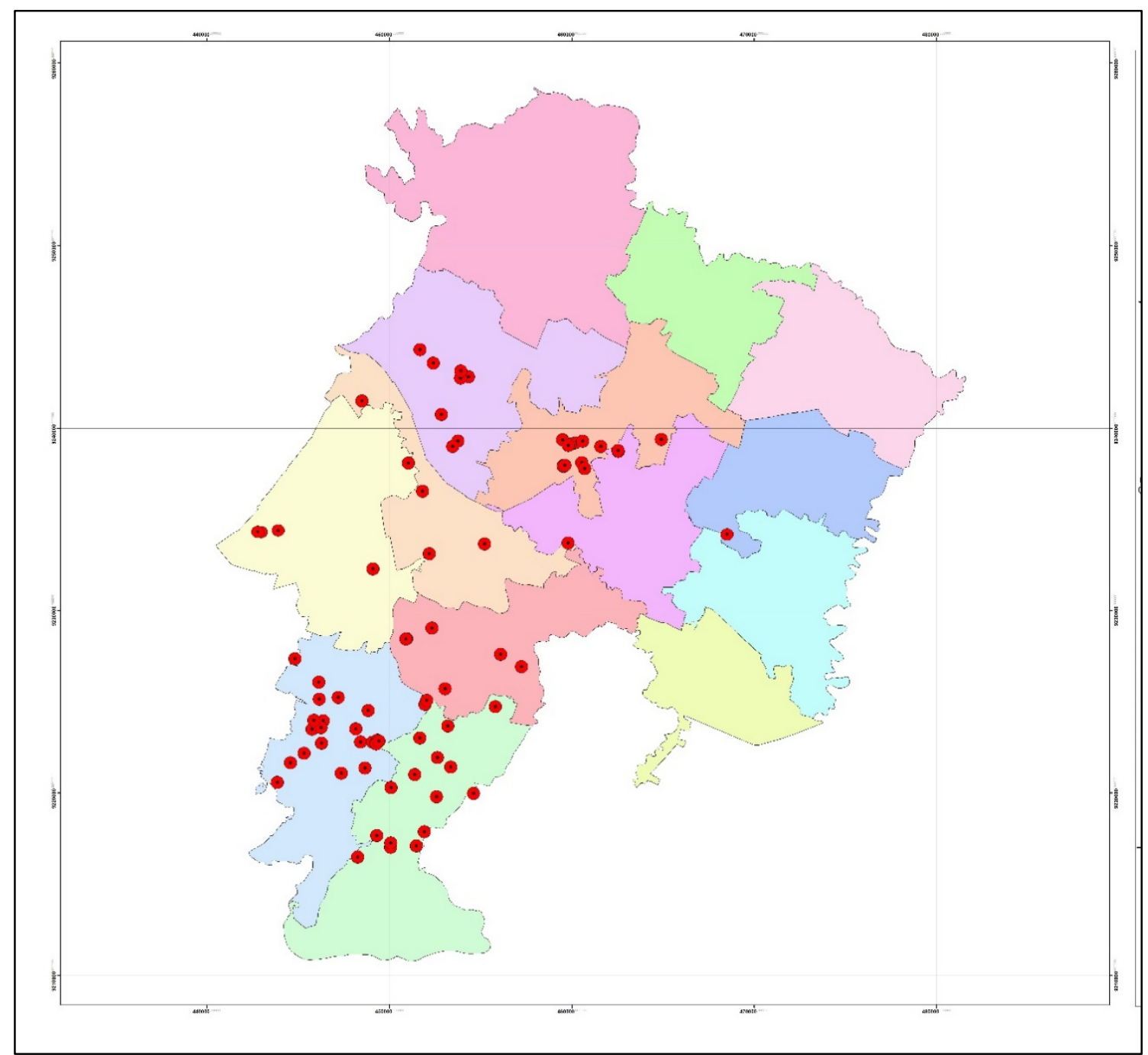

Gambar 2. Peta sebaran kasus leptospirosis di Kabupaten Demak tahun 2011-2016.

Tabel 1. Kondisi lingkungan di sekitar rumah penderita leptospirosis di Kabupaten Demak Tahun 2016

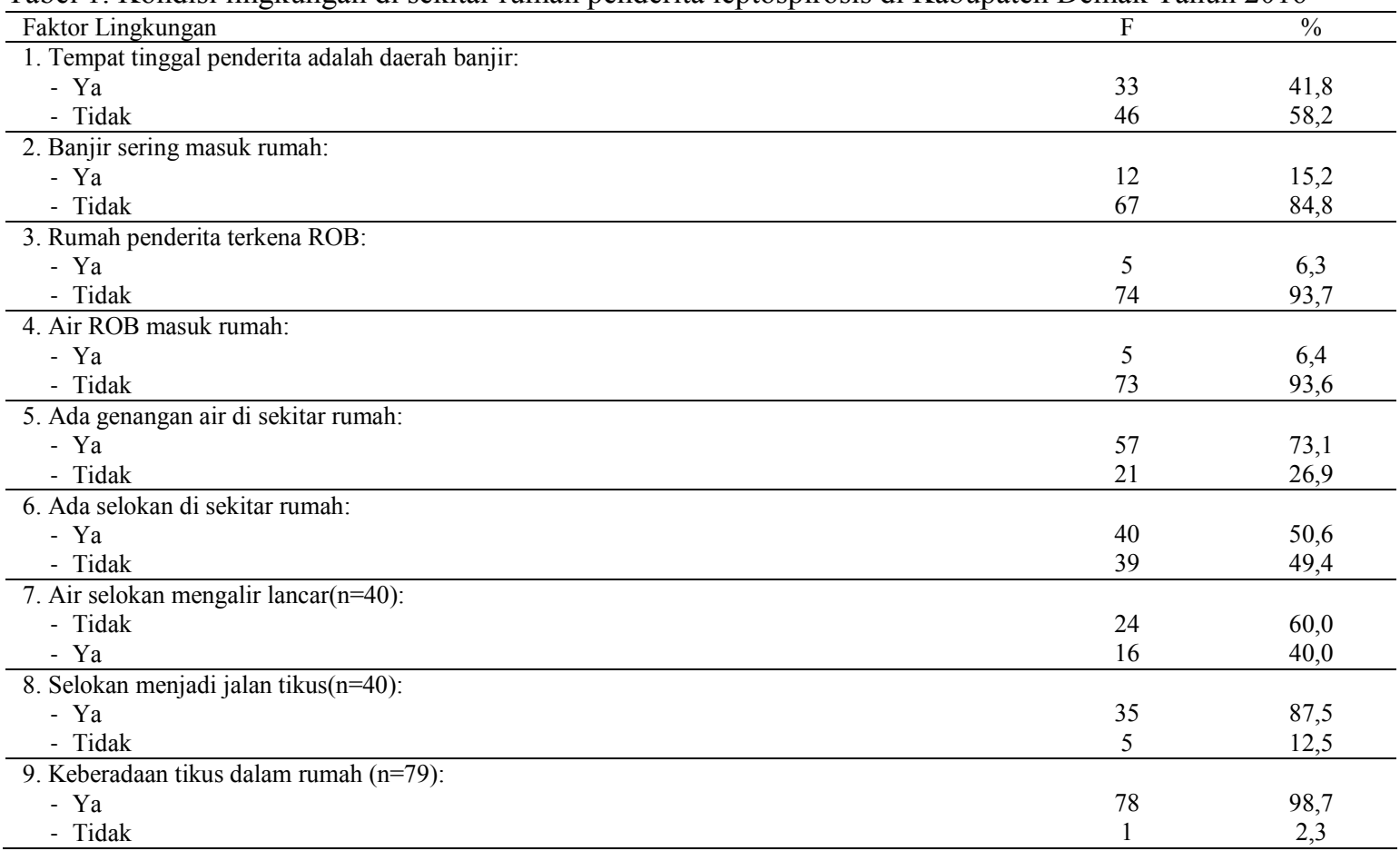


Genangan air ini sangat potensial sebagai media penularan leptospirosis. Hal ini sesuai dengan pernyataan bahwa leptospirosis beresiko terhadap individu yang terpapar air yang terkontaminasi Leptospira sp. Kejadian leptospirosis pada manusia banyak ditemukan pada pekerja pembersih selokan yang selalu terpapar oleh genangan air. ${ }^{11}$

Selain itu juga ditemukan adanya selokan di sekitar rumah penderita $(50,6 \%)$. Hasil pengamatan menunjukkan kondisi selokan tidak mengalir lancar $(60 \%)$. Selokan tersebut juga dimanfaatkan untuk jalan tikus. Hasil wawancara dengan penderita diperoleh informasi bahwa sebanyak $87,5 \%$ penderita menyatakan selokan tersebut digunakan sebagai jalan tikus. Kondisi ini menjadi pendorong adanya tikus dalam rumah-rumah penduduk. Sebanyak 98,7\% penderita menyatakan bahwa sering ditemukan adanya tikus dalam rumah mereka. Populasi yang mudah terjangkit penyakit leptospirosis adalah usia produktif dengan karakteristik tempat tinggal, merupakan daerah padat penduduk, banyak reservoir, lingkungan sering terjadi genangan air, dan lingkungan kumuh yang banya tikusnya. Tikus biasanya kencing di genangan air. ${ }^{14}$ Air yang mengandung kencing tikus sangat potensial untuk terjadinya infeksi orang yang terpapar dengan air tersebut. Selain itu, kejadian infeksi yang disebabkan oleh bakteri leptospira patogen dapat meningkat karena terjadinya bencana alam seperti banjir, gempa bumi, dan saat terjadi peningkatan jumlah yang berlipat ganda dari binatang pengerat yang merupakan sumber infeksi sekali sekaligus sebagai reservoir. ${ }^{15}$

Keberadaan genangan air ini patut menjadi perhatian dikarenakan hasil pemeriksaan air yang dilakukan oleh peneliti-peneliti sebelumnya menemukan adanya positif bakteri Leptospira sp. Hasil pemeriksaan bakteri Leptospira $s p$ pada 8 titik pengambilan sampel air di Kecamatan Bonang Kabupaten Demak menunjukkan terdapat air yang positif mengandung bakteri Leptospira sp yaitu air yang berasal dari aliran air (parit yang airnya berasal dari aliran sungai Tuntang). Kondisi parit tersebut mengalir lambat, ditumbuhi tanaman air, agak keruh, $\mathrm{pH} 8,33$, suhu air $26,1^{\circ} \mathrm{C}$, kandungan sisa chlor $<0,1$ $\mathrm{mg} / 1 .{ }^{13}$ Penelitian oleh Dyah juga menunjukkan bahwa dari seluruh sampel air yang diperiksa, sampel air positif mengandung DNA Leptospira patogenik terbanyak ditemukan di Kecamatan Mranggen $(20 \%) .{ }^{16}$ Hal ini yang dimungkinkan sebagai dugaan penyebab awal Kecamatan Mranggen menjadi wilayah dengan kasus leptospirosis tertinggi pada akhir-akhir ini.

\section{Kondisi lingkungan biologis}

Leptospirosis merupakan penyakit yang membutuhkan media dalam penularan. Salah satu media penularannya adalah binatang. Oleh karena itu, pada penelitian ini dilakukan identifikan beberapa jenis binatang yang dimungkinkan dapat sebagai reservoar maupun penyebaran leptospirosis. Hasil identifikasi dengan wawancara diperoleh informasi seperti tabel 2.

Tabel 2. Keberadaan binatang di rumah penderita leptospirosis di Kabupaten Demak tahun 2016

\begin{tabular}{lcc}
\hline \multicolumn{1}{c}{ Faktor Biologis } & $\mathrm{F}$ & $\%$ \\
\hline 1. Keberadaan tikus dalam rumah: & & \\
- Ya & 78 & 98,7 \\
- Tidak & 1 & 2,3 \\
\hline 2. Keberadaan kucing dalam rumah: & & \\
- Ya & 3 & 3,8 \\
- Tidak & 76 & 96,2 \\
\hline
\end{tabular}

Berdasarkan tabel 2 dapat diketahui bahwa lingkungan bilogis cukup mendukung kemungkinan terjadinya penyebaran kasus leptospirosis di lokasi penelitian. Hasil wawancara dengan penderita diperoleh informasi bahwa sebanyak 98,7\% menyatakan ada tikus di dalam rumah mereka. Selain tikus, ada binatang lain yang dipelihara oleh penderita yaitu kucing $(3,8 \%)$. Tikus merupakan salah satu binatang yang mempunyai kontribusi terhadap penyebaran penyakit leptospirosis. Hasil penelitian sebelumnya telah melakukan penangkapan tikus yang dilakukan pada empat lokasi (Tridonorejo A, Tridonorejo B, Moro dan Sumberejo) di Kecamatan Bonang. Hasil penangkapan menunjukkan bahwa trap success pada daerah tersebut tinggi ( $>7 \%)$. Jenis tikus yang tertangkap di 4 wilayah adalah sebagai berikut, tikus rumah atau Rattus tanezumi yaitu sebanyak 159 ekor, jenis kelamin $R$. Tanezumi betina 50,31\%, jantan $32,70 \%$ dan muda $16,98 \%{ }^{13}$ Dengan demikian keberadaan tikus perlu mendapat perhatian untuk pengendaliannya agar tidak menjadi perantara penyebaran leptospirosis.

\section{Perilaku penderita}

Perilaku masyarakat mempunyai pengaruh dalam penyebaran dan penularan penyakit leptospirosis. Pada penelitian ini dilakukan pengukuran terhadap dua aspek perilaku yang dimungkinkan berkaitan dengan leptospirosis. Dua aspek perilaku tersebut ditanyakan keberadaannya saat sebelum subyek mengalami sakit leptospirosis. Hasil wawancara diperoleh informasi seperti tabel 3.

Berdasarkan tabel 3 diketahui bahwa sebagian besar penderita $(66,7 \%)$ mempunyai kebiasaan tidak menggunakan alas kaki dalam melakukan kegiatan sehari-hari. Hal ini sangat wajar karena kebanyakan penderita adalah petani pedesaan yang sering pergi ke sawah menjalankan aktivitas mereka. Kebiasaan ini sangat memungkinkan mendukung terjadinya kasus leptospirosis.

Tabel 3. Perilaku subyek penelitian dengan kejadian leptospirosis di Kabupaten Demak tahun 2016

\begin{tabular}{lcc}
\hline Aspek Perilaku & $\mathrm{f}$ & $(\%)$ \\
\hline 1. Kebiasaan menggunakan alas kaki: & & \\
- Tidak & 52 & 66,7 \\
- Ya & 26 & 33,3 \\
\hline 2. Kebiasaan mandi di sungai $(\mathrm{n}=79):$ & & \\
- Ya & 2 & 2,5 \\
- Tidak & 77 & 97,5 \\
\hline
\end{tabular}


Namun demikian, personal higiene mereka sangat baik dalam hal membersihkan diri. Hanya 2,5\% penderita yang menyatakan mereka mempunyai kebiasaan mandi di sungai. Kedua kebiasaan tersebut sangat memungkinkan seseorang kontak dengan bakteri Leptospira sp. yang ada di air. Analisis statistik membuktikan ada hubungan antara kebiasaan mandi/ mencuci di sungai. Adanya hubungan kebiasaan mandi/ mencuci di sungai karena responden kasus memiliki aktivitas berenang dan mandi di sungai ketika sungai meluap di musim kemarau. ${ }^{17}$ Penelitian di tiga daerah (Semarang, Demak, dan Pati) juga membuktikan ada hubungan antara kebiasaan mandi/mencuci di sungai dengan kejadian leptospirosis $(p<0,05 ; \mathrm{OR}=7,3 ; 95 \% \mathrm{CI}=1,55-33,99)$. Sehingga terbukti bahwa kebiasaan mandi/ mencuci di sungai merupakan faktor risiko terhadap kejadian leptospirosis. ${ }^{9}$

\section{SIMPULAN}

Kasus leptospirosis selama kurun waktu 20112016 di Kabupaten Demak banyak diderita oleh kelompok laki-laki (66\%). Sebagian besar mereka $(67,4 \%)$ bekerja sebagai petani. Wilayah dengan jumlah kasus tertinggi beturut-turut adalah Kecamatan Mranggen, Karangawen, dan Demak. Analisis spasial menunjukkan bahwa kasus leptospirosis lebih banyak terkonsentrasi di bagian selatan wilayah Kabupaten Demak, yaitu Kecamatan Mranggen dan Karangawen. Kedua wilayah tersebut merupakan daerah pertanian/persawaan yang mempunyai riwayat banjir.

\section{DAFTAR PUSTAKA}

1. Scott M, Geoffey, Coleman J, Timothy. Leptospirosis: Manson's Tropical Diseases, Twenty second edition Chapter 70: 1161, 2003.

2. Widoyono. Penyakit Tropis, Epidemiologi, Penularan, Pencegahan dan Pemberantasannya. Jakarta: Erlangga, 2008.

3. Widarso HS dan Wilfried, Kebijakan Departemen Kesehatan dalam Penanggulangan Letospirosis di Indonesia, Kumpulan Makalah Simposium Leptospirosis, Badan Penerbit Universitas Diponegoro, 2002.

4. Esem Saban et al. Impact of Clinical and Laboratory Findings on Prognosis in Leptospirosis. Swiss Midical Weekly, 2004: p.347-352.

5. WHO. Human Leptospirosis: Guidance for diagnosis, Surveillance and Control. Genewa, 2003.
6. Dinas Kesehatan Kabupaten Demak. Profil Kesehatan Kabupaten Demak. Demak: 2015.

7. Priyanto A. Faktor-faktor Risiko yang Berpengaruh terhadap Kejadian Leptospirosis Studi Kasus di Kabupaten Demak. Universitas Diponegoro, Semarang, 2008.

8. Hadisaputro S. Faktor-faktor Risiko Leptospirosis, Kumpulan Makalah Simposium Leptospirosis. Badan Penerbit Universitas Diponegoro, Semarang, 2002.

9. Riyaningsih, Hadisaputro S, Suhartono. Faktor Risiko Lingkungan Kejadian Leptospirosis di Jawa Tengah (Studi Kasus di Kota Semarang, Kabupaten Demak dan Pati). Jurnal Kesehat Lingkung Indones April 2012. Vol. 11 No. 2: hal. 87-94.

10. Tri Ramadhani, Bambang Yunianto. Reservoir dan Kasus Leptospirosis di Wilayah Kejadian Luar Biasa. Jurnal Kesehatan Masyarakat Nasional Vol. 7 No. 4, November 2012.

11. WHO. Human Leptospirosis: Guidance for Diagnosis, Surveillance and Control. Genewa, 2003.

12. Farida DH, Ristiyanto. Distribusi dan faktor risiko lingkungan penularan leptospirosis di Kabupaten Demak, Jawa Tengah. Media Litbang Kesehatan Tahun 2008 Vol XVIII No. 4, hal. 193-201.

13. Bina Ikawati, Sulistyani, Nurjazuli. Analisis Karakteristik Lingkungan Pada Kejadian Leptospirosis di Kabupaten Demak Jawa Tengah Tahun 2009. Jurnal Kesehat Lingkung Indones Oktober 2009 Vol. 8 No. 2: hal. 39-45.

14. Depkes RI, Pedoman Tatalaksana Kasus dan Pemeriksaan Laboratorium Leptospirosis di Rumah Sakit. Ditjen Pemberantasan Penyakit Menular dan Penyehatan Lingkungan, Jakarta, 2003.

15.Z. Cermakova, O Ryskova. Laboratory Diagnosis of Leptospirosis. Folio Mikrobiol, 2005: p.345347.

16. Dyah Widiastuti, Rr. Anggun Paramita Djati. Kontaminasi Leptospira Patogenik pada Air Konsumsi di Pemukiman Kabupaten Demak. BALABA Vol.11 No.2, Desember 2015: hal. 8996.

17. Dwi Sarwani Sri Rejeki, Sri Nurlaela, Devi OctavianaPemetaan dan Analisis Faktor Risiko Leptospirosis. Jurnal Kesehatan Masyarakat Nasional Vol. 8, No. 4, November 2013: hal.179186. 